\title{
Downward Regulation of Plasma LH by LHRH Agonist, Leuprolide Acetate, Resulting in Inhibited Renal Growth and Function in the Castrated Male Rat
}

\author{
KaOru NOMURA, Yuko SATO, Makoto WATANABE, \\ Nobuo HORIBA, Makoto UJIHARA, SHohzou TORAYA, AND \\ Hiroshi DEMURA \\ Department of Medicine, Institute of Clinical Endocrinology, \\ Tokyo Women's Medical College, Tokyo 162, Japan
}

\begin{abstract}
We previously reported that ovine and porcine luteinizing hormone ( $\mathrm{LH}$ ) stimulated kidney growth in castrated hypophysectomized rats. Our present study focuses on the physiological role of the renotropic activity of LH isoforms. Plasma LH levels were decreased to $10 \%$ of that of castrated control rats by injections of a slow-releasing LHRH agonist, leuprolide acetate, from microcapsules. Compared to controls, which were injected with microcapsules only, the kidney weight in leuprolide-treated castrated rats decreased $12 \%$. Renal protein and DNA contents decreased significantly. Body, liver and spleen weights were not changed by the treatment, however. This effect on the kidney was not observed in castrated hypophysectomized rats, suggesting that leuprolide affected the kidneys indirectly, rather than directly, by suppressing LH secretion. In leuprolide-treated castrated rats, urinary fractional excretion of sodium (FENa) increased, indicating suppressed renal function at the proximal tubules. We concluded that the secretion of renotropically active LH isoforms was regulated at least partially by LHRH and played a physiological role in growth and the function of the proximal tubules.
\end{abstract}

Key words: LHRH, LH, Kidney, DNA.

(Endocrinol Japon 38: 693-697, 1991)

LH AND OTHER glycoprotein hormones consist of an array of isoforms with heterogeneous oligosaccharide and polypeptide structures [1]. We previously reported that some ovine and porcine LH isoforms stimulated $\left[{ }^{3} \mathrm{H}\right]$ thymidine incorporation into renal DNA in castrated hypophysectomized rats [2, 3], and increased renal weight and protein and DNA contents in castrated hypophysectomized mice [4]. To further clarify the role of $\mathrm{LH}$ isoforms in maintaining kidney growth, we studied the effect of the selective removal of LH isoforms on kidney growth.

We injected microcapsules containing a potent

Received: July 10, 1991

Accepted: October 7, 1991

Correspondence to: Dr. Kaoru NOMURA, Department of Medicine, Institute of Clinical Endocrinology, Tokyo Women's Medical College, 8-1 Kawada-cho, Shinjuku-ku, Tokyo 162, Japan.
LHRH agonist, leuprolide [D-Leu ${ }^{6}-\left(\right.$ des-Gly ${ }^{1-}$ $\mathrm{NH}_{2}$ )-LHRH ethylamide] acetate, subcutaneously into castrated rats and studied its effect on plasma LH and kidney weight. Microcapsules slowly released leuprolide for a month, causing LH secretion to be suppressed [5], which may demonstrate the effect on the kidney of selectively reducing gonadotropins. We studied changes in both renal growth and renal function. Rats were castrated to exlude the indirect effect on the kidney of leuprolide via testosterone. Castrated hypophysectomized rats were also studied to clarify whether or not leuprolide affected the kidney directly.

\section{Materials and Methods}

Jla: Wistar male rats were purchased from Nihon Ikagaku Doubutsu Shizai Kenkyujo, 
Tokyo. The rats were castrated or castrated and hypophysectomized at four weeks of age. Hypophysectomy was performed by the external auditory canal method [6]. Leuprolide acetate $(0.3$ $\mathrm{mg}$ ) in microcapsules [5], kindly donated by Takeda Chemical Industries, Ltd., Osaka, were injected subcutaneously. Microcapsules without leuprolide were similarly injected into control rats. Four weeks after the first injection of microcapsules, the rats were sacrificed or given a second injection of microcapsules with or without $0.66 \mathrm{mg}$ of leuprolide. The rats given second injections were sacrificed seven weeks after the first injection. In castrated hypophysectomized rats, the second dose was $0.3 \mathrm{mg}$ rather than $0.66 \mathrm{mg}$ because of their lower body weights. Blood, kidney, liver, and spleen were collected for further study. Kidney, liver, and spleen were lyophilized to measure their dry weights, then immersed and homogenized in distilled water to measure their protein and DNA contents as described previously [4]. The plasma LH concentration was measured by specific RIA provided by the National Hormone and Pituitary Program, NIDDK, Baltimore, MD [7] with NIDDK-rLH-RP-3 as a standard. The creatinine concentration was determined by an automated picric acid method and sodium was determined by

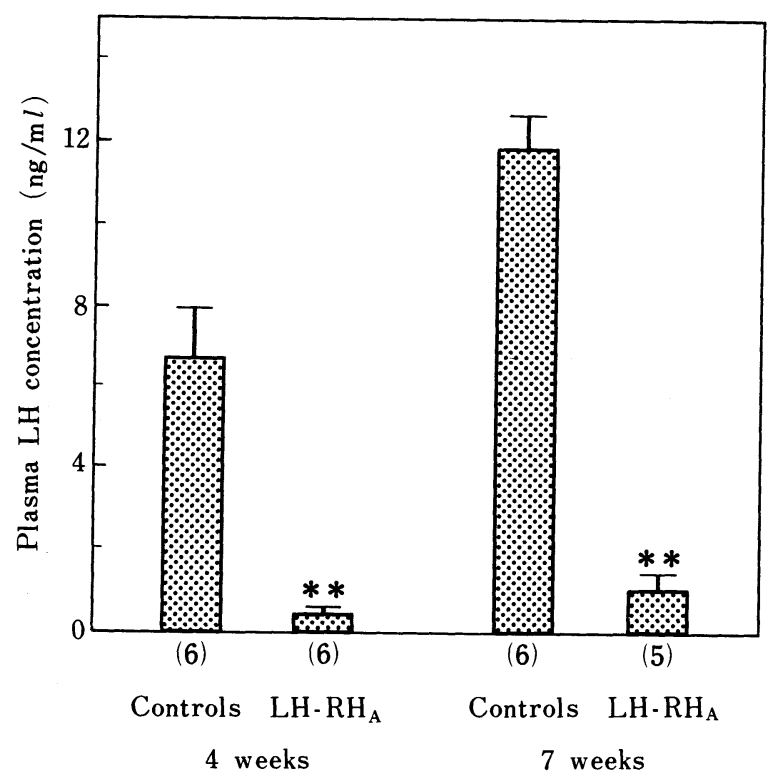

Fig. 1. Plasma LH concentration after treatment with leuprolide $\left(\mathrm{LH}-\mathrm{RH}_{\mathrm{A}}\right)$. Plasma $\mathrm{LH}$ concentration was significantly decreased in castrated rats by four and seven weeks' treatment. ${ }^{* *} \mathrm{p}<0.01$ vs. controls. flame photometry. The results were reported as the mean $\pm \mathrm{SE}$. The analysis of variance and Duncan's new multiple range test were used for statistical analysis [8].

\section{Results}

\section{Effects of leuprolide on castrated rats}

Leuprolide decreased the plasma LH level to about $10 \%$ of that of control rats both at four and seven weeks (Fig. 1). As shown in Table 1, the body, liver, and spleen weights of leuprolidetreated rats did not differ from those of the controls. The dry kidney weight decreased to $88 \%$ of that of the controls at seven weeks (Table 1). Renal protein and DNA contents were also signi-
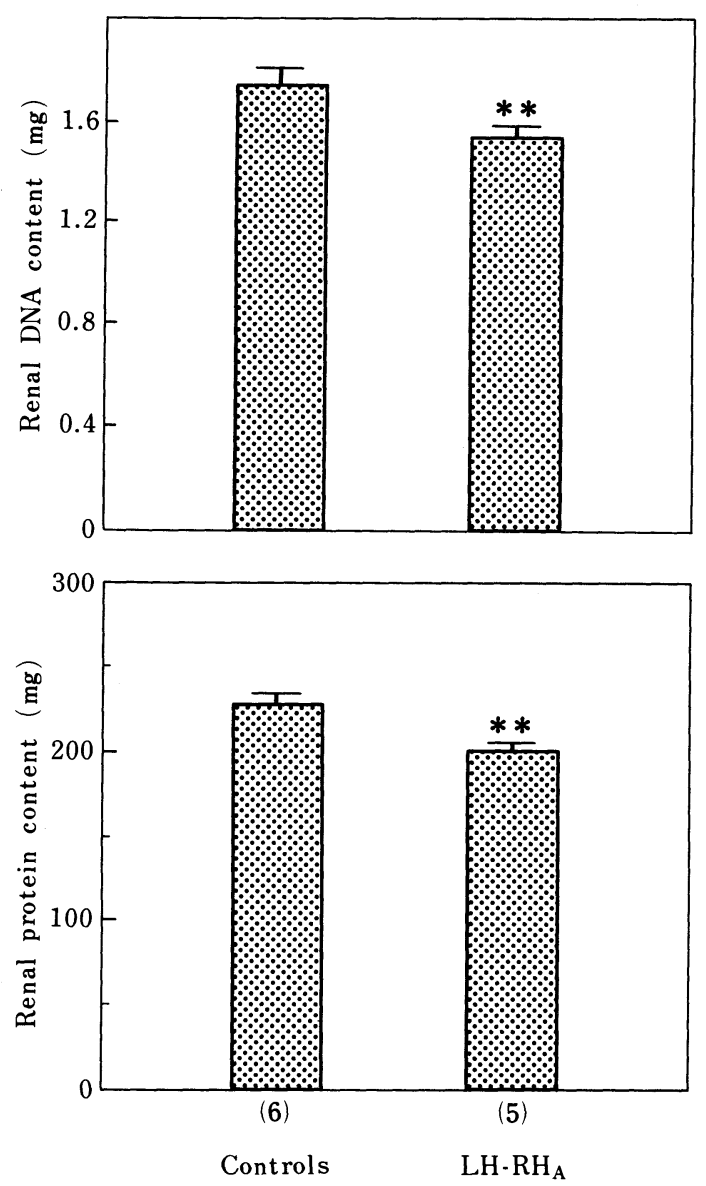

Fig. 2. Renal contents of protein and DNA after treatment with leuprolide $\left(\mathrm{LH}-\mathrm{RH}_{\mathrm{A}}\right)$. Renal protein and DNA contents were significantly decreased in castrated rats by seven weeks' treatment with leuprolide. $* * p<0.01$ vs. controls. 
Table 1. Effects of LH-RH agonist on body, kidney, liver, and spleen weights

\begin{tabular}{|c|c|c|c|c|c|}
\hline Treatment period & \multicolumn{2}{|c|}{ Body weight (g) } & $\begin{array}{l}\text { kidney weight } \\
\text { (g) }\end{array}$ & $\begin{array}{l}\text { liver weight } \\
(\mathrm{g})\end{array}$ & $\begin{array}{l}\text { spleen weight } \\
\text { (g) }\end{array}$ \\
\hline \multicolumn{6}{|c|}{ Experiments on castrated rats } \\
\hline $\begin{array}{ll}\text { Controls } & 4 \text { weeks }(6) \\
\mathrm{LH}^{-} \mathrm{RH}_{\mathrm{A}} & 4 \text { weeks }(6)\end{array}$ & $\begin{array}{l}86.2 \pm 1.1 \\
86.4 \pm 1.6\end{array}$ & $\begin{array}{l}234.9 \pm 4.2 \\
234.0 \pm 4.2\end{array}$ & $\begin{array}{l}0.363 \pm 0.006 \\
0.376 \pm 0.010\end{array}$ & $\begin{array}{l}3.208 \pm 0.117 \\
3.098 \pm 0.066\end{array}$ & $\begin{array}{l}0.171 \pm 0.006 \\
0.170 \pm 0.004\end{array}$ \\
\hline $\begin{array}{ll}\text { Controls } & 7 \text { weeks (6) } \\
\text { LH-RHA }_{\mathrm{A}} & 7 \text { weeks (5) }\end{array}$ & $\begin{array}{l}88.7 \pm 1.1 \\
86.2 \pm 2.5\end{array}$ & $\begin{array}{l}309.0 \pm 9.0 \\
308.6 \pm 7.6\end{array}$ & $\begin{array}{l}0.468 \pm 0.018 \\
0.414 \pm 0.005^{\text {a) }}\end{array}$ & $\begin{array}{l}3.754 \pm 0.157 \\
3.649 \pm 0.113\end{array}$ & $\begin{array}{l}0.197 \pm 0.008 \\
0.174 \pm 0.012\end{array}$ \\
\hline \multicolumn{6}{|c|}{ Experiments on castrated hypophysectomized rats } \\
\hline $\begin{array}{ll}\text { Controls } & 4 \text { weeks }(11) \\
\text { LH-RH }_{\mathrm{A}} & 4 \text { weeks } \\
(10)\end{array}$ & $\begin{array}{l}108.3 \pm 1.3 \\
108.1 \pm 1.1\end{array}$ & $\begin{array}{l}114.5 \pm 2.9 \\
107.7 \pm 3.2\end{array}$ & $\begin{array}{l}0.162 \pm 0.004 \\
0.153 \pm 0.004\end{array}$ & $\begin{array}{l}1.395 \pm 0.072 \\
1.255 \pm 0.044\end{array}$ & $\begin{array}{l}\text { N.D. } \\
\text { N.D. }\end{array}$ \\
\hline $\begin{array}{l}\text { Controls } 7 \text { weeks }(7) \\
\text { LH-RH }_{\mathrm{A}} \quad 7 \text { weeks }(6)\end{array}$ & $\begin{array}{l}95.9 \pm 2.0 \\
96.2 \pm 1.6\end{array}$ & $\begin{array}{l}121.7 \pm 3.3 \\
115.0 \pm 4.4\end{array}$ & $\begin{array}{l}0.162 \pm 0.007 \\
0.161 \pm 0.006\end{array}$ & $\begin{array}{l}1.361 \pm 0.007 \\
1.176 \pm 0.063^{\mathrm{b})}\end{array}$ & $\begin{array}{l}0.066 \pm 0.004 \\
0.059 \pm 0.003\end{array}$ \\
\hline
\end{tabular}

Controls indicate rats treated with microcapsules without leuprolide. $\mathrm{LHRH}_{\mathrm{A}}$ indicates rats treated with leuprolide in microcapsules. The number in parenthesis indicates the animal number used. The dose injected is indicated in "Materials and Methods". Means \pm SEM are shown. ${ }^{a)}, \mathrm{p}<0.05$; $^{\mathrm{b})}, \mathrm{p}<0.01$ vs Controls. N.D. means not determined.
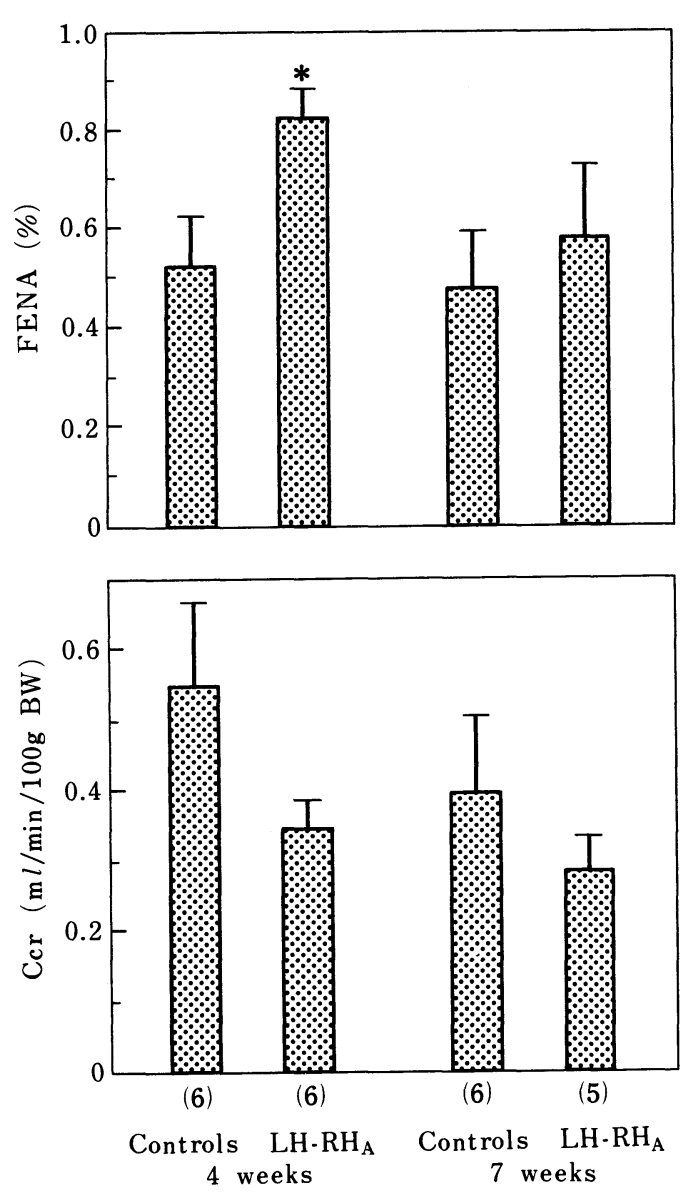

Fig. 3. Renal function after treatment with leuprolide $\left(\mathrm{LH}-\mathrm{RH}_{\mathrm{A}}\right)$. Creatinine clearance (Ccr) and fractional excretion of sodium (FENa) were determined. ${ }^{*} \mathrm{p}<0.05$ vs. controls. ficantly decreased in rats treated for seven weeks (Fig. 2). Creatinine clearance tended to be lower in leuprolide-treated rats. FENa tended to be higher in leuprolide-treated rats with a significant difference at four weeks of treatment (Fig. 3).

Effects of leuprolide on castrated hypophysectomized rats Hypophysectomy reduced body and organ weights. Treatment with leuprolide did not affect body, kidney or spleen weights, but reduced liver weight further at seven weeks (Table 1).

\section{Discussion}

A significant relationship has been reported between testicular function and renal growth [9]. Premature male rats undergo renal growth with increased renal DNA contents (renal hyperplasia). After puberty, however, the increased plasma level of testicular androgen inhibits renal DNA synthesis and stimulates renal protein synthesis (renal hypertrophy). When mature male rats were castrated, renal DNA synthesis was again initiated [9]. Because our present work was to study the physiological role of renotropically active LH isoforms characterized as mitogenic for the proximal tubules, we used castrated rats in this experiment, thereby excluding the influence of testicular androgen. In castrated rats treated with leuprolide, plasma LH levels decreased significant- 
ly to $10 \%$ of those of castrated control rats but were still slightly higher than those of noncastrated male rats $(0.1-0.2 \mathrm{ng} / \mathrm{m} l)$ [7]. Although the aim of our study, i.e., the removal of plasma LH, was partially achieved, the outcome may not represent the maximum effect. When leuprolidetreated and untreated castrated rats were compared, the only significant effect observed was in kidney weight, but not in body, liver, and spleen weights. Leuprolide did not decrease kidney weight in castrated hypophysectomized rats, suggesting that this kidney-specific effect was not directly from leuprolide but was the result of decreased plasma levels of gonadotropins, LH, and FSH. Because FSH had no renotropic effect $[10,11]$, the decrease in kidney weight may be attributable to reduced $\mathrm{LH}$. It was also evident that the secretion of renotropically active LH isoforms was regulated at least partially by $\mathrm{LHRH}$.

The decrease in kidney weight due to leuprolide treatment was relatively minor, only by $12 \%$ from that of the controls. The effect was much weaker than that induced by hypophysectomy, perhaps for the following reasons: First, $\mathrm{LH}$ isoforms stimulated proliferation in only limited cells, proximal tubular cells, among the heterogeneous renal cells [12]. Second, plasma LH levels were not suppressed completely, so the effect may not be the maximum possible. Third, other pituitary factors may contribute to maintain kidney growth directly or indirectly. For example, although GH,
IGF-I, thyroid hormone and testosterone did not stimulate renal DNA synthesis $[13,11]$, these hormones exhibit anabolic effects on the kidney [14-16] and maintain kidney growth.

Liver weight was decreased after seven weeks of treatment with leuprolide in castrated hypophysectomized rats. This finding is inconsistent with our previous one that, in castrated hypophysectomized mice, five daily injections of renotropically active ovine $\mathrm{LH}$ isoforms reduced liver weights [4]. Such a difference remains to be further studied.

Renal function also appeared to be inhibited in castrated rats treated with leuprolide. Sodium reabsorption at the proximal tubules, FENa, was reduced significantly at four weeks, so it seems likely that renotropically active LH isoforms stimulated both renal growth and the function of proximal tubules. A more detailed study may clarify the role of $\mathrm{LH}$ isoforms with regard to the functions of the proximal tubules.

\section{Acknowledgments}

We thank Ms. Jun Setoguchi for editing this manuscript. This study was supported in part by the Foundation for Growth Science in Japan and by a Grant-in-Aid from the Japanese Ministry of Education, Science, and Culture for Encouragement of Young Scientists (03771838).

\section{References}

1. Keel BA, Grotjan Jr HE (1989) Luteinizing hormone microheterogeneity. In: Keel BA, Grotjan Jr HE (eds) Microheterogeneity of Glycoprotein Hormones. CRC Press, Florida, 149-184.

2. Nomura K, Tsunasawa S, Ohmura K, Sakiyama F, Shizume K (1988) Renotropic activity in ovine luteinizing hormone-isoform(s). Endocrinology 123: $700-712$.

3. Nomura K, Ohmura K, Nakamura Y, Horiba N, Shirakura Y, Sato Y, Ujihara M, Ohki K, Shizume K (1989) Porcine luteinizing hormone isoform(s): relationship between their molecular structures, and renotropic versus gonadotropic activities. $\mathrm{En}$ docrinology 124: 712-719.

4. Nomura K, Puett DW, Puett D, Shizume K, Liddle GW (1989) Extragonadal effects of luteinizing hormone in mice. Acta Endocrinol (Copenh) 121: $587-594$.
5. Okada H, Heya T, Ogawa Y, Shimamoto T (1988) One-month release injectable microcapsules of a luteinizing hormone-releasing hormone agonist (leuprolide acetate) for treating experimental endometriosis in rats. $J$ Pharmacol Exp Ther 244: $744-750$.

6. Tanaka A (1955) A simple method for hypophysectomy on rats. Modification of Koyama's external auditory canal method. Shionogi Kenkyusho Nempo 5: 678-680.

7. Ujihara $\mathrm{M}$, Nomura $\mathrm{K}$, Toraya $\mathrm{S}$, Demura $\mathrm{H}$ (1990) Uninephrectomy inducing quantiative and qualitative changes in $\mathrm{LH}$ isoforms in the male rat. Acta Endocrinol (Copenh) 123: 365-370.

8. Snedecor GW, Cochran WG (1980) Statistical Methods. Iowa State University Press, Ames, Iowa, 215-237.

9. Zumoff B, Pachter MR (1964) Studies of rat kidney 
and liver growth using total nuclear counts. $A m \mathrm{~J}$ Anat 114: 479-493.

10. Nomura K, Puett D, Nicholson WE, Liddle GW (1982) Partial purification and characterization of a renotropic fraction from ovine pituitaries. Proc Natl Acad Sci USA 79: 6675-6679.

11. Nomura K, Demura H, Shizume K (1985) Stimulation of renal deoxyribonucleic acid synthesis and its inhibition by testosterone and thyroxine. Endocrinology 116: 616-621.

12. Nomura K, Mizuhira V, Shiihashi M, Sugiura Y, Shizume K (1985) Renotropic stimulation of DNA synthesis of proximal tubules and endotherial cells in the outer medulla. Nephron 39: 255-260.

13. Nomura K, Nose J, Shizume K (1988) Growth hormone inhibits renotropic action of luteinizing hormone-isoform(s). Endocrinol Japon 35: 413-419. 14. McGuire DM, Tormanen CD, Segal IS, Van Pilsum JF (1980) The effect of growth hormone and thyroxine on the amount of L-arginine: glycine admidinotransferase in kidneys of hypophysectomized rats. J Biol Chem 255: 1152-1159.

15. Buul-Offers S, Brande JL, Dumoleijn L, Feijlbrief M, Hoogerbrugge CM, Klundert PLM (1982) Cellular growth in organs of dwarf mice during treatment with growth hormone, thyroxine and plasma fractions containing somatomedin activity. Acta Endocrinol (Copenh) 99: 150-160.

16. Pfeiffer CA, Emmel VM, Gardner WU (1940) Renal hypertrophy in mice receiving estrogens and androgens. Yale J Biol Med 12: 493-501. 